\title{
The Allocation of Attorney's Fees After Mills v. Electric Auto-Lite Co.
}

The legal system of the United States has traditionally refused to award attorney's fees to the successful litigant. ${ }^{1}$ Defenders of the rule emphasize that it encourages the resolution of controversies through the courts, enhances predictability, and promotes the security and confidence of the prospective litigant. ${ }^{2}$ Recently, however, the rule has been the focus of substantial criticism. ${ }^{3}$ Commentators point out that while the citizen need not pay his opponent's fees, neither can he recover the cost of his own lawyer. As a result, soaring legal fees have vitiated the impact of lowered financial risk and have effectively excluded the poor (and increasingly the middle class) ${ }^{5}$ from active participation in the legal process.

1 The United States may be unique among the nations of the world in its failure to grant legal fees to the successful party. Ehrenzweig, Reimbursement of Counsel Fees and the Great Society, 54 CaLIF. L. REv. 792, 793 (1966).

2 For classic discussions of the pros and cons of the American fee rule compare McCormick, Counsel Fees and Other Expenses of Litigation as an Element of Damages, 15 Minn. L. REv. 619 (1931), with Goodhart, Costs, 38 YALE L.J. 849 (1929), and Note, Distribution of Legal Expenses Among Litigants, 49 YALE L.J. 699 (1940).

3 Four major articles in the 1960's, all critical of the fee system and all cited by the Mills court, are Kuenzel, The Attorney's Fee: Why Not a Cost of Litigation?, 49 IowA L. REv. 75, 78 (1963); Stoebuck, Counsel Fees Included in Costs: A Logical Development, 38 Colo. L. REv. 202 (1966); Note, Attomey's Fees: Where Shall the Ultimate Burden Lie?, 20 VAND. L. REv. 1216 (1967); and Ehrenzweig, supra note 1.

4 Carlin \& Howard, Legal Representation and Class Justice, 12 U.C.L.A.L. REv. 381 (1964). One of the distinctive anomalies at the core of the American fee system is that while it is responsible for the exclusion of the poor from the legal process, it is defended as a protection for the indigent who might otherwise be "unjustly discouraged from instituting actions to vindicate their rights." Fleischmann Distilling Corp. v. Maier Brewing Co., 386 U.S. 714, 718 (1967); accord, Farmer v. Arabian Am. Oil Co., 379 U.S. 227, 237 (1964) (Goldberg, J., concurring). The traditional argument answers the question: What would be the effect on the poor of increased litigating risks? Whatever the merits of the answer, the question is wrong because it implies the reality of a free access system which does not exist in fact. Better questions might be: Would more meritorious claims by poor citizens be excluded by the risks of fee shifting than are now excluded by their inability to retain legal counsel? Should the operative criteria for exclusion be economic power or the individual's own judgment as to the merits of his case?

5 Comment, Providing Legal Services for the Middle Class in Civil Matters: The Problem, the Duty, and a Solution, 26 U. PITT. L. REv. 811, 814 (1965). The resulting situation in which practical legal rights have become the exclusive companion of the well-to-do is the peculiar gift of the traditional fee rule to our society. Economic power becomes determinative of legal rights irrespective of its position in the case. Wealthy plaintiffs can realize awards on groundless claims "because the defendant will prefer to 
The system's two-pronged response to this dilemma-the contingent fee device and the legal aid office-has proven inadequate. The former has only a limited applicability, confined principally to the personal injury area. ${ }^{6}$ Legal aid, on the other hand, fails because there are too few offices, and too few talented and experienced lawyers willing to devote themselves to low income work.7 Moreover, as Ehrenzweig bitterly notes: "[A]Il the law now offers the little man, outside that second-rate court at some places and at some times, is charity. Legal aid, rather than legal right."8

In the recent case of Mills $v$. Electric Auto-Lite Co., ${ }^{9}$ the Supreme Court may have taken steps to alter the traditional rule. Mills involved a stockholders' suit that failed to fit any of the traditional exceptions to the fee doctrine. Not only did the Court grant attorneys' fees to the plaintiff, but the broad language of the opinion suggests that basic changes in the fee-denying rule may soon follow. This comment will examine (1) the setting of the Mills decision, (2) the language of the case itself, and (3) the impact of the language on the traditional fee system.

\section{The Background of the American Fee System Prior to Mills}

The federal courts have never completely followed the traditional anti-fee-shifting doctrine. ${ }^{10}$ Exceptions fall roughly into three categories.

pay the plaintiff an amount less than the expense of fighting the case. This is the nuisance value of the suit . . a legalized form of blackmail." Kuenzel, supra note 3, at 78. On the other hand, the moneyed defendant "irrespective of the justice of his position, can wrest victory from his 'little' opponent by designedly protracting litigation, imposing an unbearable burden of attorney fees that can never be recouped." Stoebuck, supra note 3, at 202.

B Where the anticipated award is not large, the contingent fee device is inoperativecreating a gap in practical legal rights which cuts hardest in the area of civil liberties. Kuenzel, supra note 3, at 78-86. Yet the contingent fee device is controversial even in those areas within which it is operative. For perspective on the "ambulance chasing" issue compare F.B. MacKinnon, Contingent FEES FOR LEgal SERvices (1964), with the less enthusiastic Note, Lawyer's Tightrope-Use and Abuse of Fees, 41 CorNell L. REv. $683,699-700$ (1956). Whatever the ethical effects on lawyers, the psychological impact on the poor may be far more important. In $1924 \mathrm{R}$. H. Smith wrote, "The man whose leg or arm has been cut off would prefer to accept half of the amount awarded him by a jury than to receive nothing through his inability to gain his day in court." R.H. SMITH, JUSTICE AND THE POOR 85 (1924). In 1970 when mass violence finds its origin in perceptions of helplessness and being cheated, half as much justice may no longer be acceptable. See REPORT OF THE PRESIDENT'S COMMISSION ON LAW ENFORCEMENT AND ADMINISTRATION OF Justice, The Challenge of Crime in a Free Society 37-38 (1967). See also Note, supta note 3 , at 1226 , suggesting that a bar anxious to maintain the contingent fee device maintains a powerful vested interest in retaining the traditional fee rule.

7 Carlin \& Howard, supra note 4 , at $410,416-17$.

8 Ehrenzweig, supra note 1 , at 796.

o 396 U.S. 375 (1970).

10 An examination of fee shifting under state law is beyond the scope of this paper. 
First, a limited number of federal statutes provide for mandatory fee shifting where the successful plaintiff has been injured by a violation of those statutes, ${ }^{11}$ or where the defendant is forced to comply with the order of an administrative agency. ${ }^{12}$ This exception represents a positive legislative determination as to the benefits of augmenting statutory regulations with private fee incentives.

The government has set up a regulatory system for the benefit of persons in the plaintiff's class. . . . Suits by plaintiffs, if well founded, are in the public interest. Therefore, the cost of prosecuting successful suits should be borne not by those who were victims but by those who have violated the regulations and caused the damage. ${ }^{13}$

A different philosophy is reflected in the second exception to the anti-fee doctrine. This exception consists of federal statutes which permit fee shifting to either plaintiff or defendant at the discretion of the court. Discretionary fee shifting under these statutes has generally been limited to situations where bad faith triggers fee transfer under a punishment rationale. ${ }^{14}$ Thus, fee granting under discretionary statutes re-

Stoebuck's article details a long list of statutes authorizing fee transfer under state law in everything from actions for divorce to actions for unpaid wages. "Taken together, the cases in which substantial attorney fees may be recovered comprise a sizable portion of American litigation ...." Stoebuck, supra note 3, at 210. Instances of fee shifting on the federal and state levels contrast sharply with traditional doctrine which labels fee transfer as impractical. "[T] his grafted litigation might possibly be more animated and protracted than in the original cause." Maier Brewing Co. v. Fleischmann Distilling Corp., 359 F.2d 156, 159 (9th Cir. 1966).

11 Clayton Act, 15 U.S.C. $\$ 15$ (1964); Communications Act of 1934, 47 U.S.C. § 206 (1964). As a corollary to the injury requirement, at least under the Clayton Act, the courts have held that no recovery of fees is possible where only injunctive relief is requested. Alden-Rochelle, Inc. v. American Soc'y of Composers, Authors \& Publishers, 80 F. Supp. 888,889 (S.D.N.Y. 1948).

12 Packers \& Stockyards Act, 7 U.S.C. $\S 210(f)$ (1964); Perishable Agricultural Commodities Act, 7 U.S.C. $\$ 499 \mathrm{~g}(\mathrm{~b})$ (1964); Railway Labor Act, 45 U.S.C. $\S 153$ (p) (1964); Interstate Commerce Act, 49 U.S.C. § 16(2) (1964).

13 Futchinson v. William G. Barry, Inc., 50 F. Supp. 292, 298 (D. Mass. 1943).

14 For example, the Securities Act of 1933 levies fees where the suit or defense is "without merit," 15 U.S.C. § 77k(e) (1964); the Servicemen's Readjustment Act for violations committed "knowingly," 38 U.S.C. $\& 1822(\mathrm{~b})$ (1964); and fees may not be shifted under the Trust Indenture Act if the litigant can prove that he acted in "good faith," 15 U.S.C. \& 77www(a) (1964). Where specific statutory language is absent, the courts generally imply a good faith requirement, denying fee transfer under copyright law where the infringement results from honest mistake, Ziegelheim v. Flohr, 119 F. Supp. 324, 329 (E.D.N.Y. 1954); and under patent laws where there is a failure to find "unfairness or bad faith in the conduct of the Iosing party," Keuffel \& Esser Co. v. Masback, Inc., 131 F. Supp. 237, 238 (E.D.N.Y. 1955). While the punishment rationale has limited awards to plaintiffs, even more restrictive criteria are applied to fee awards to defendants. Note, Attorney's Fees as an Element of Costs: The Copyright Experience, 4 GEORGIA L. REv. 571, 581 (1970). 
quires the party seeking to recover attorney's fees to win not only the merits of his case, but the sympathy of the court as well..$^{15}$ Fee transfer under this punishment rationale implies significant limitations on the level of fee shifting. It focuses on the motives of the parties and ignores the broader issue of the restraints placed on private law enforcement by the high costs of litigation. Finally, when the awards are made, the amounts granted are generally regarded as insufficient; they are more closely related to the damage award than to the actual time spent in preparation for the case..$^{16}$

The third exception consists of a number of extra-statutory, discretionary categories developed by the federal courts under color of their historic equity jurisdiction. Reflecting the discretionary practice under the statutes, the courts have chosen to shift fees in a limited number of areas, generally under a punishment rationale. ${ }^{17}$ However, there does exist a class of cases not based upon a punishment rationale. This "fund" category relates to that situation where plaintiff's representative action results in the creation of a fund, the economic benefit of which is shared by all the members of the represented class. The Supreme Court long ago held that failure to shift fees in this situation "would not only be unjust to [the plaintiff] but it would give to the other parties entitled to participate in the benefits of the fund an unfair advantage." 18 Here the fee transfer is triggered not by the wrongdoing of the defendant, but by the positive benefit attendant to the plaintiff's action.

The equitable impulse to grant fees has made itself felt even in the face of statutory schemes where the court's discretion seems highly limited. In a cause of action arising under a statute which is itself silent on fees, complex questions are evoked as to whether the legislative remedies are supplementary or limiting. The force of the fee shifting impulse in a statutory context is demonstrated by three decades of developments in the trademark area.

As late as 1937, the Second Circuit recognized a theoretical power to grant fees in trademark infringement suits but concluded that "the

15 Note, supra note 14 , at 576 .

$16 \mathrm{Id}$. at 588.

17 Fees are shifted in admiralty cases where "the default was willful and persistent," Vaughan v. Atkinson, 369 U.S. 527, 531 (1962); in contempt cases where "willfulness inherent in the contemptuous act is a major consideration," In re Federal Facilities Realty Trust, 227 F.2d 657, 658 (7th Cir. 1955); and generally, as in Rolax v. Atlantic Coast Line R.R., 186 F.2d 473, 481 (4th Cir. 1950), where litigants "have been subjected to discriminatory and oppressive conduct." In the trademark exception "the absence of fraud .. . precludes allowance of counsel fees to plaintiff." Fancee Free Mfg. Co. v. Fancy Free Fashions, Inc., 148 F. Supp. 825, 831 (S.D.N.Y. 1957).

18 Trustees v. Greenough, 105 U.S. 527, 532 (1882). 
allowance of costs has with practical uniformity been restricted to those authorized by the fee bill or some other statutory provision." 19 However, only three years later, the Seventh Circuit in Alladin Mfg. Co. v. Mantle Lamp Co., ${ }^{20}$ relying simply on its equitable powers and neither citing precedent nor providing discussion in support of the result, granted fees against a "wilful and fraudulent" infringer.

By the late 1950's the preference of the federal courts on the subject of fees was quite apparent. Alladin had become the departure point for a long line of decisions transferring fees in trademark infringement suits brought under the Lanham Act, which was itself silent on the fee question. ${ }^{21}$ Even in the face of intricate questions of statutory intent, the courts maintained that fees could be granted.

Mere silence and inaction by Congress cannot be held to have repealed what has been found to be a well established judicial power. Even though the Lanham Act may have been intended to be an integrated and comprehensive set of rules for trademark regulation and litigation to the exclusion of all conflicting rules, the retention of discretionary judicial power over the fixing of costs does not seem such a threat of inconsistency that it should by implication be held pre-empted or repealed by the Act. ${ }^{22}$

The legal system was involved in what seemed to be a timely and appropriate reaction to a new sense of awareness about the relationship between legal fees and the practical availability of justice. Just as criticism of the American rule on fees had reached an all time high, ${ }^{23}$ the courts were making use of their equitable power to grant fees with a regularity previously unmatched. Nevertheless, it was at this very point that the Supreme Court chose to take a stunning step backward, and in Fleischmann Distilling Corp. v. Maier Brewing Co. ${ }^{24}$ not only

19 Gold Dust Corp. v. Hoffenberg, 87 F.2d 451, 453 (2d Cir. 1937). The court denied fees to the successful defendant after plaintiff failed to prove that "Silver Dust" was an infringement of plaintiff's trademark "Gold Dust."

20 Alladin Mfg. Co. v. Mantle Lamp Co., 116 F.2d 708, 717 (7th Cir. 1941). The successful plaintiff, a lamp manufacturer, had incurred legal expenses of over $\$ 18,000$ in proving that his trademark "Alladin" had been infringed. The court awarded counsel fees noting that "this sum was recoverable as compensatory damages."

21 See, e.g., Wolfe v. National Lead Co., 272 F.2d 867 (9th Cir. 1959); National Van Lines v. Dean, 287 F.2d 688 (9th Cir. 1956); Maternally Yours, Inc. v. Your Maternity Shop, Inc., 234 F.2d 538 (2d Cir. 1956); Admiral Corp. v. Penco, Inc., 203 F.2d 517 (2d Cir. 1953).

22 A. Smith Bowman Distillery, Inc. v. Schenley Distilleries, Inc., 204 F. Supp. 374, 377 (D. Del. 1962).

23 Authorities cited note 3 supra.

24386 U.S. 714 (1967). 
destroyed the trademark exception, but created a reaction reaching the whole system, chilling the granting of attorney's fees in areas far afield of trademark litigation.

In Fleischmann, the Ninth Circuit had held that the congressional silence in the Lanham Act, and the lack of any positive rationale in the many fee-granting precedents, required the denial of fee transfer. ${ }^{25}$ Surprisingly, the Supreme Court affirmed with a hard line defense of the traditional fee doctrine. The Court noted the uncertainties of litigation, ${ }^{26}$ the necessity that "one should not be penalized for merely defending or prosecuting a lawsuit," 27 and the "time, expense, and difficulties of proof inherent in the question of litigating what constitutes reasonable attorney's fees."28

Fleischmann recognized only three limited, non-statutory exceptions to the general fee rule, ${ }^{29}$ and concluded that "[w]hen a cause of action has been created by a statute which expressly provides the remedies for vindication of the cause, other remedies should not readily be implied." 30 The chilling effect on the lower courts soon became apparent as attorney's fees were denied on the basis of Fleischmann in actions brought under the Interstate Commerce $\mathrm{Act}^{31}$ and the Securities Exchange Act of $1934,{ }^{32}$ both of which were silent on the question of attorney's fees in the relevant sections. It seemed that Fleischmann had

25 Maier Brewing Co. v. Fleischmann Distilling Corp., 359 F.2d 156, 159-61 (9th Cir. 1966).

28386 U.S. at 718.

27 Id.

28 Id.

29 The exceptions recognized involved the admiralty, the fund and the contempt cases. 386 U.S. at 718-19. See note 17 supra.

30386 U.S. at 720.

31 Michigan Pub. Serv. Comm'n v. Mackinac Transp. Co., 43 F.R.D. 202 (W.D. Mich. 1967), denied fees in an action brought under 49 U.S.C. $\$ 1(20)$ (1964). That section is silent on attorney's fees. $\$ \S 8,15(9)$, and $16(2)$ of Part $I$ of the Interstate Commerce Act specifically provide for the recovery of attorney's fees. 49 U.S.C. $\S \S 8,15(9), 16(2)$ (1964). An identical result was achieved by the Eighth Circuit in Missouri Pac. R.R. v. Slayton, 407 F.2d 1078 (8th Cir. 1969). Here plaintiffs obtained a declaratory judgment as to their voting rights on a plan of consolidation which resulted in separate voting by Class $A$ and Class $B$ stockholders and the defeat of the proposed consolidation. In the action brought under the Interstate Commerce Act, 49 U.S.C. §§ 5, 5(11) (1964), the court held that "in our view the recent case of Fleischmann Distilling Corp. v. Maier Brewing Co. ... controls the issue here. . . . As we read Fleischmann, exceptions to the general rule are sparingly granted. The factual situation here does not fall within any exceptions recognized by Fleischmann." 407 F.2d at 1082-83.

32 Chaney v. Western States Title Ins. Co., 292 F. Supp. 376 (D. Utah 1968), where fees were denied in an action brought under the Securities Exchange Act of 1984, § 10(b), 15 U.S.C. 78j (1964). Fees were also denied in Stevens v. Abbott, Procter \& Paine, 288 F. Supp. 836 (E.D. Va. 1968), where the court found a violation of $\S 10$ of the Securities Exchange Act of 1934 prohibiting manipulative or deceptive devices in connection with sales of securities. 15 U.S.C. \$ 78j (1964). 
ushered in an era of conservatism even at a time when the fee system was undergoing its greatest criticism. ${ }^{33}$ The voices urging change had not only failed to alter official policy, but had seen thirty years of growth in court-created exceptions suddenly wiped out.

Nevertheless, in 1968 a civil rights case gave the Supreme Court the opportunity to register an apparent modification of its previously hostile attitude toward fee shifting. Newman v. Piggie Park Enterprises, Inc..$^{34}$ arose under Title II of the Civil Rights Act of $1964^{35}$ which includes the following provision:

In any action commenced pursuant to this subchapter, the court, in its discretion, may allow the prevailing party, other than the United States, a reasonable attorney's fee as part of the costs, and the United States shall be liable for costs the same as a private person. ${ }^{36}$

Characteristically, the section had evolved into a means of punishment levied against recalcitrant defendants who had to be prodded by repeated suits before accepting the legislative mandate on integration. ${ }^{37}$

It was this punishment aspect which had caused the circuit court to refuse to award fees below: "No litigant ought to be punished under the guise of an award of counsel fees (or in any other manner) from taking a position in court in which he honestly believes-however lacking in merit that position may be."38

In its decision, the full importance of which is realized only in juxtaposition with Mills, the Supreme Court held that "one who succeeds in obtaining an injunction under that Title should ordinarily recover an attorney's fee unless circumstances should render such an award unjust."39

In what appeared to be a marked change from its Fleischmann position, the Supreme Court went out of its way to increase the incidence of fee granting, at least in the civil rights area. ${ }^{40}$ More importantly, the court de-emphasized the problem-laden punishment theory and provided instead the groundwork for a positive theory of fee shifting for the American system. The Court stated:

\footnotetext{
33 See authorities cited note 3 supra.

84390 U.S. 400 (1968).

35 42 U.S.C. $\S 2000 \mathrm{a}(c)(2)$ (1964), prohibiting discrimination in restaurants affecting interstate commerce within the meaning of the statute.

3642 U.S.C. \& 2000a-3(b) (1964).

37 See Cato v. Parham, 293 F. Supp. 1375, 1878 (E.D.N.C. 1968).

38377 F.2d 433, 437 (4th Gir. 1967).

39390 U.S. at 402.

40 See Note, Civil Rights-Attorney's Fees, 4 Harv. Civ. Rugrts-Civ. LiB. L. REv. 223 (1969), concluding at 225: "No logical imperative Ieads to the conclusion that Congress intended a mandatory fee. If Congress had so intended, it could have explicitly done so."
} 
A Title II suit is ... private in form only. When a plaintiff brings an action under that Title, he cannot recover damages. If he obtains an injunction, he does so not for himself alone but also as a "private attorney general," vindicating a policy that Congress considered of the highest priority. ${ }^{41}$

Following Piggie Park, the lower federal courts have shown a marked propensity to award fees in civil rights cases. For example, in litigation involving school desegregation, ${ }^{42}$ legislative reapportionment, ${ }^{43}$ and police misconduct, ${ }^{44}$ lower federal courts awarded fees without express congressional authorization. In Mills the Supreme Court was squarely confronted with the issue of whether this emerging liberalism of the federal courts should be curtailed or encouraged.

\section{Mills v. Electric Auto-Lite Co.}

In Mills stockholders in Electric Auto-Lite Company sought to dissolve a 1936 merger of their company with Merganthaler Linotype. The legal rationale was an alleged violation of rule 14(a) of the Securities Exchange Act of 1934, forbidding solicitation of shareholders'

41390 U.S. at 401-02. The theory of private attorneys general which is now being used effectively to encourage fee shifting, has previously had impact upon determinations of who has standing to challenge administrative action. See K.C. DAvis, 3 ADMinistratrve LAw TREATISE § 22.05, at 225 (1958). A landmark opinion is that of Judge Jerome Frank in Associated Indus. v. Ickes, 134 F.2d 694, 704 (2d Cir. 1943), dismissed as moot, 320 U.S. 707 (1943): "Congress can constitutionally enact a statute conferring on any non-official person ... authority to bring a suit to prevent an action by an officer in violation of his statutory powers ... even if the sole purpose is to vindicate the public interest. Such persons, so authorized, are, so to speak, private Attorney Generals."

42 Cato v. Parham, 293 F. Supp. 1375 (E.D.N.C. 1968). The action in Cato was nonstatutory, and was brought to compel desegregation conforming to the Supreme Court's interpretation of the constitutional requirements. The court cited Piggie Park saying: "While that decision is not binding here, it is suggestive." 293 F. Supp. at 1378.

43 Dyer v. Love, 307 F. Supp. 974 (N.D. Miss. 1969). Plaintiffs invoked 42 U.S.C. \$§ 1983,1988 (1964) and claimed that the alleged population disparities between districts which each elected one member to the board of supervisors constituted invidious discrimination in violation of the fourteenth amendment. Only three years earlier the same court had denied fees in a similar case, Damon v. Lauderdale County Bd. of Supervisors, 254 F. Supp. 918 (S.D. Miss. 1966), where plaintiffs brought suit to compel realignment of precincts in a county to conform with the constitutional requirements of one man-one vote. In denying fees, the court stated at 918: "It is not without significance in view of the general rule as to the award of attorneys' fees as cost, that the Congress provided in the Civil Rights Act of 1964 ... for the discretionary award of attorneys' fees in certain cases, not including the case at bar."

44 Kerr v. City of Chicago, 6 CRNM. L. REP. 2448 (7th Cir. 1970). Here a civil action was brought under 42 U.S.C. §§ 1983, 1988 (1964) alleging involuntary confession and numerous violations of plaintiff's civil rights. In granting attorney's fees the Seventh Circuit held: "Federal common law controls the question of damages in civil rights actions with the purpose being to vindicate the civil rights of individuals." 
votes by a materially misleading proxy statement. ${ }^{45}$ After ruling that the proxy statement was indeed materially misleading and remanding to the district court for consideration of the proper relief, the Supreme Court turned to the request of the Solicitor General that the plaintiffs be granted an interim award of attorneys' fees. The question had been introduced in the government's amicus curiae brief and had been almost totally ignored by the litigating parties. ${ }^{46}$

The request for fees presented major difficulties. Since only the issue of liability was before it, the Court was being asked to make an award of fees without knowing what the final resolution of the plaintiff's action would be. More importantly, the action had been brought under the statutory authority of section 14(a), which itself was completely silent on the question of fees. This was in sharp contrast to sections $9(\mathrm{e})$ and $18(a)^{47}$ of the same act in which Congress had specifically provided for fee shifting. The juxtaposition seemed to bring the Mills facts directly under the Fleischmann doctrine that exceptions to the traditional fee rule should not be developed "in the context of statutory causes of action for which the legislature had provided intricate remedies." ${ }^{48}$ Another factor which seemed to make 14(a) an inappropriate setting for fee transfer was its failure to authorize in explicit terms a private right of action. That private right for stockholders had itself been implied earlier in the landmark case of J. I. Case Co. v. Borak.49 Thus the circumstances seemed to support the traditional responsethat fee shifting in this case was unauthorized by congressional will.50

45 Securities Exchange Act of 1934, § 14(a), 48 Stat. 895 (1934), as amended I5 U.S.C. $\S 78 \mathrm{n}(\mathrm{a})$ (1964).

It shall be unlawful for any person, by use of the mails or by any means or instrumentality of interstate commerce or of any facility of any national securities exchange or otherwise to solicit or to permit the use of his name to solicit any proxy or consent or authorization in respect of any security (other than an exempted security) registered on any national securities exchange in contravention of such rules and regulations as the Commission may prescribe as necessary or appropriate in the public interest or for the protection of investors.

46 The government maintained, "... in our view, the plaintiffs, who have established a violation of the securities laws by their corporation and its officials, are entitled to litigation expenses and reasonable attorneys' fees. . . ." Brief for the United States as Amicus Suriae at 19, Mills v. Electric Auto-Lite Co., 396 U.S. 375 (1970).

$47 \$ 9(e)$ and $18(a)$ concern respectively manipulation of securities prices and misleading statements in documents filed with the Commissioner. 15 U.S.C. $\$ \S 78 i(e), 78 r(a)$ (1964).

48386 U.S. at 719.

49377 U.S. 426 (1964).

50 Justice Black concluded in dissent, "The courts are interpreters, not creators, of legal rights to recover and if there is a need for recovery of attorneys' fees to effectuate the policies of the Act here involved, that need should in my judgment be met by Congress, not by this Court." 396 U.S. at 397. One district court held, in a like situation, that to grant fees here "would be basing an implication on an implication-an implied right to attorney's fees based on an implied civil liability." That court went on to note that the authorities including Fleischmann "at best deflate the idea and at worst prohibit it." Chaney v. Western States Title Ins. Co., 292 F. Supp. 376, 379 (D. Utah 1968). 
Nevertheless, the Mills Court chose to interpret congressional silence not as a prohibition, but as an authorization to the court to decide the attorneys' fee issue. ${ }^{51}$ The silence which two years earlier in Fleischmann had meant the absence of congressional intent now became a mandate to create and implement private remedies. The Court in Mills does not clearly repudiate Fleischmann; rather, it takes some pains to distinguish the earlier case and to limit its conclusions to the Lanham Act, where Congress had "meticulously detailed the remedies available to a plaintiff who proves his valid trademark had been infringed."

While the Lanham Act admittedly did provide remedies not available to the successful Securities Exchange Act plaintiff, the change in philosophy since Fleischmann was obvious. Gone was the broad language indicating that exceptions to the fee rule were few and far between. Also gone were the implications that these exceptions were out of place in a statutory cause of action. Now "these sections merely enforce an additional penalty against the wrongdoer."53 The analytical process is completely reversed. Where previously the courts were led to start with the traditional rule and then ascertain whether the case fell into one of the three Fleischmann-approved exceptions, now they are to start with the equitable power of the courts to grant appropriate remedies with the burden on the other side to prove a legislative "purpose to circumscribe the courts' power."54

Having surmounted the obstacle of congressional silence, the Court was still faced with the task of locating a viable fee shifting rationale. Nothing in the facts of Mills justified granting fees under any of the traditional exceptions to the fee rule. ${ }^{55}$ Fee recovery in a stockholder's suit was normally accomplished under only a "fund" rationale, ${ }^{56}$ but here no monetary recovery was sought. The Court needed a development which in its own words had moved far "from the traditional

51 ". . . leaving the courts with the task, faced by this Court in Borak, of deciding whether a private right of action should be implied. The courts must similarly determine whether the special circumstances exist that would justify an award of attorneys' fees ...." 396 U.S. at 391 .

52 Id. (quoting Fleichmann). The Court continues, "By contrast, we cannot fairly infer from the Securities Exchange Act of 1934 a purpose to circumscribe the courts' power to grant appropriate remedies." The Court does not seem overly concerned with maintaining the traditional facade of uniformity on the fee question: "both the courts and Congress have developed exceptions to this rule for situations in which overriding considerations indicate the need for such a recovery." 396 U.S. at 391-92.

68396 U.S. at 390 (quoting Smolowe v. Delendo Corp., 136 F.2d 231, 241 (2d Cir. 1943)). 54396 U.S. at 391.

55 While Smolowe v. Delendo, 136 F.2d 231, 241 (2d Gir. 1943), provided a circuit court precedent for ignoring the silence-as-bar rule, there the rationale for the actual fee transfer was the creation of a fund.

56 See generally Hornstein, The Counsel Fee in Stockholder's Derivative Suits, 39 COLUM. L. REV. 784 (1939). 
metes and bounds of the doctrine."'st The development to which the Court turned had been initiated by a Supreme Court case, but from that point on had been entirely the child of the state courts. The seminal decision was Sprague $v$. Ticonic National Bank, ${ }^{58}$ in which the plaintiff, by vindicating her rights to a trust, established the rights of fourteen others whom she never purported to represent. This was not the creation of a fund in the traditional sense, but Justice Frankfurter, speaking for the Court, refused to hold the exception within its formal limits:

[T] he formalities of the litigation-the absence of an avowed class suit or the creation of a fund, as it were, through stare decisis rather than through a decree-hardly touch the power of equity in doing justice as between a party and the beneficiaries of his litigation. ${ }^{59}$

It was in the state courts that the "formalities" really began to yield to newly emerging policy imperatives. Abrams $v$. Textile Realty Corp ${ }^{60}$ and Bosch v. Meeker Cooperative Power and Light Ass' $n,{ }^{61}$ both cited in Mills, adopted a law enforcement-as-benefit rationale to award fees to stockholder plaintiffs even where no fund was created. In Abrams the defendant argued that while plaintiff's suit had prevented ultra vires acts, economically speaking it had been detrimental to the corporation. ${ }^{62}$ However, the New York Supreme Court responded that "the law cannot refuse to recognize as beneficial full observance of the law. The law cannot hold that corporate interests are better served by actions outside the law than within the law." Supreme Court in Bosch affirmed the concept of law enforcement-asbenefit, cautioning only that the benefit must be "substantial."64

In support of its move to a non-fund fee-shifting rationale, the Mills Court, like the court in Bosch, made substantial reference to a number of articles by George Hornstein. As Hornstein described the problem, the stockholder's suit was the case of David and Goliath, with David unable to afford the slingshot. Laws which authorized private

57396 U.S. at 393.

58307 U.S. 161 (1939).

59 Id. at 167.

60 Abrams v. Textile Realty Corp., 97 N.Y.S.2d 492 (Sup. Ct. 1949). Here the stockholder proved that the corporation's manner of entering into a mortgage agreement was contrary to the existing indenture and voting trust agreement.

61257 Minn. 362, 101 N.W.2d 423 (1960). Plaintiff obtained a declaratory judgment that the election of directors conducted by mail as well as a proposed amendment to the bylaws was illegal.

6297 N.Y.S.2d at 496.

$63 \mathrm{Id}$.

64257 Minn. at 366, 101 N.W.2d at 426. 
actions against corporate defendants were rendered ineffective by the traditional fee rule. ${ }^{65}$ The practical reality was that few stockholders could afford the high cost of corporate litigation, ${ }^{86}$ especially as augmented by the deliberate delaying tactics of the corporate defendant. Hornstein concluded that effective enforcement mandated the shifting of attorney's fees to the successful plaintiff as a "necessary concomitant of allowing the stockholder's derivative suit, which is vital to the exposure and redress of corporate abuse." 67

Perhaps as important as Hornstein's definition of the situation was his ability to label the formulated remedy. In describing the process by which the shifting of fees would facilitate stockholder's suits, thereby promoting fair conduct throughout the corporate world, Hornstein hit upon the term "legal" or "corporate therapeutics." 68 The term had the advantage of bringing to mind a positive process image of the function of increasing law enforcement by shifting the fee burden.

In accepting the rulings of Abrams and Bosch, together with the Hornstein terminology, the Mills Court legitimized a stockholder's suit fee exception based solely on law enforcement policy considerations. ${ }^{69}$ The Court was concerned not with the benefit of this suit to these shareholders, but with the benefit of this type of suit to the public interest: " $[P]$ rivate stockholders' actions of this sort 'involve corporate therapeutics,' and furnish a benefit to all shareholders by providing an important means of enforcement of the proxy statute."70 Reimbursement for attorney's fees is a means of enforcing the law. In short, the Court granted an award for acting as a private attorney general. Moreover, the Court stated its basic principle in terms not limited to stockholder's suits, authorizing the shifting of fees in all cases "where a plaintiff has successfully maintained a suit, usually on behalf of a class,

65 Hornstein, Legal Therapeutics-The "Salvage" Factor in Counsel Fee Awards, 69 HARv. L. REv, 658 (1956).

68 Hornstein, supra note 56 , at 791 .

67 Id. at 816.

68 Hornstein, supra note 65.

69 This is the narrow holding of the court: "[P]etitioners, who have established a violation of the securities laws by their corporation and its officials, should be reimbursed by the corporation or its survivor for the costs of establishing the violation." 396 U.S. at 389-90. This narrow holding was responsive to the amicus curiae brief of the United States which in originally raising the issue had asserted that in cases which involve "corporate therapeutics" the absence of express statutory authorization should be no bar to fee granting. Brief for the United States as Amicus Curiae at 21.

70396 U.S. at 396. A further indication that the benefit language acts as little more than a facade for societal policy imperatives is the criterion delineated in the Mills fact situation where the reference point is not the corporate defendant but the Congress. "[T] he stress placed by Congress on the importance of fair and. informed corporate suffrage leads to the conclusion that, in vindicating the statutory policy, petitioners have rendered a substantial service to the corporation and its shareholders." Id. 
that benefits a group of others in the same manner as himself." 71 In thus broadening the concept of benefit as well as its area of application, the Court introduced the potential for radical changes in the traditional fee doctrine.

\section{Implications of the Mills Dogtrine}

It is impossible to predict whether the courts will take full advantage of the opportunities implicit in the Mills language. At the very least, the opinion should resolve the ambiguities created by the parallel existence of Fleischmann and Piggie Park. Mills may properly be viewed as an extension of the policy initiated in Piggie Park. Both cases disregarded the traditional but unsatisfactory punishment rationale, and in its place established the outlines of a positive theory of fee transfer. Whether it be labeled "private attorney general" or "benefit" or "legal therapeutics," the moving concept is the same-whatever the theoretical disadvantages, the need to provide the individual with private law enforcing power makes fee shifting a practical necessity.

Mills is an affirmation of the pre-Fleischmann and post-Piggie Park fee shifting trend. As such it should result in some defrosting of the Fleischmann chill and in a resumption in the expansion of fee transfer within the traditional exceptions. The Mills doctrine provides a counter-pole to the traditional anti-fee-shifting dogma and thereby provides the theoretical substructure so evidently lacking in the trademark cases. ${ }^{72}$ In this context the "benefit" and "therapeutics" language which for so long animated the stockholder's development can be expected to be equally effective in other areas. Moreover, the courts now have the opportunity to de-emphasize the old process of scrutinizing each factual situation for the elements of "bad faith" necessary to trigger fee transfer under the old punishment rationale. ${ }^{78}$ Now the dominant element in the decision-making process may be the emergence of a consensus as to the societal benefits of encouraging private law enforcement. This shift in analytical perspective from the variables of a given factual situation to the constant of a public policy consensus may have an

71396 U.S. at 392. According to the Court, the law has developed such that fees may be shifted "where the litigation has conferred a substantial benefit on the members of an ascertainable class, and where the court's jurisdiction over the subject matter of the suit makes possible an award that will operate to spread the costs proportionately among them." 396 U.S. at 393-94.

72 See generally Maier Brewing Co. v. Fleischmann Distilling Corp., 359 F.2d 156 (9th Cir. 1966).

73 See Hartford Nat'l Bank \& Trust Co. v. E.F. Drew \& Co., 188 F. Supp. 353, 363 n.52 (D. Del. 1960), stating: "The cases on allowance of attorneys fees could be multiplied by the hundreds both plus and minus depending on the facts of each case." 
effect tantamount to the Piggie Park language-making future discretionary fee shifting ordinary.

The broader impact of Mills lies in its "benefit" language augmented by the simultaneous adoption of the supportive therapeutics principle. "Legal therapeutics" is essentially a restatement of the deterrence theory with the emphasis switched from public to private action. ${ }^{74}$ It confronts the problem of prohibitively high litigation costs, and as such need not be limited to corporate finance or stockholder's suits. Hornstein's corporate world is nothing but a microcosm of the society-wide effects of the traditional rule, and if successful litigation to enforce the law makes for a better corporate world, it also makes for a world of viable civil rights, more consumer protection and less air pollution. ${ }^{75}$ The following examples illustrate the potential impact of a positive Mills development.

Actions challenging administrative decisions provide a primary protection against feeble law enforcement of pollution laws, and both courts and legislatures have moved to strengthen that protection. Previously restrictive rules on standing to sue have been broadened ${ }^{76}$ and the National Environmental Policy Act of $1969^{77}$ has given new scope to the power of judicial review. However, the cost of litigation has chilled private challenges to administrative decision:

The trial may be lengthy and complex. Its conduct is a difficult burden for the attorneys having the burden of proof assigned to them by the substantial evidence-rational-basis rule, and

74 "They are therapeutic, helping to maintain the health of our corporate system. In hundreds of suits which would not have been instituted without the allure of generous compensation, a miscarriage of justice has been prevented. At the same time the record of litigated cases is prophylactic-a deterrent to future wrongdoing. Every successful suit duly rewarded encourages other suits to redress misconduct and by the same token discourages misconduct which would occasion suit." Hornstein, supra note 65, at 663 .

75 It must be recognized, however, that the actual response to a fee incentive may vary tremendously because of factors outside the control of the courts. Attorney's fees are often not the only deterrent to increased private law enforcement. Where, as in civil rights, the gap between the present crisis and full protection is a result of lack of trust, fear, ignorance and the political distastefulness of civil rights suits, as well as the fee system, a change in the fee allocation alone can be expected to have a minimal effect. See V. Countryman, The LAwYer in Modern Society pt. VI, at 81-126 (1962).

76 See Scenic Hudson Preservation Conference v. Federal Power Comm'n, 354 F.2d 608 (2d Cir. 1965). One commentator noted that this case could result in environmental action groups becoming the "vanguard of an assault on environmental pollution through the courts." Esposito, Air and Water Pollution: What To Do While Waiting for Washington, 5 HARV. Crv. Rights-Crv. LIB. L. REv. 32, 36 (1970).

7788 Stat. 852 (1970). The act provides a more thoroughgoing process, and an expanded concept of the kinds of data and expertise relevant to an evaluation of an administrative decision. Sive, Some Thoughts of an Environmental Lawyer in the Wilderness of Administrative Law, 70 CoLuM. L. REv. 612, 649.50 (1970). 
who are not compensated at all, or compensated at a small fraction of the amounts to which they are ordinarily entitled. ${ }^{78}$

This kind of suit offers an excellent opportunity for an expansive Mills effect. It comes to the court fused with the clear public policy imperatives of a statutory regulation. In addition, the relationship of the parties is reflective of the Mills factual situation, since the government may be said to stand in the same relation to the citizen as the corporation to the stockholder. Forcing the government to pay fees is a method of spreading the burden of enforcement among all the taxpayers, who are the beneficiaries of that enforcement. Such a result falls easily within the Mills language of benefit "on the members of an ascertainable class," 79 and an award "that will operate to spread the costs proportionately among them." 80

Mills may similarly facilitate private actions directly against the violating party. This is particularly true in those areas such as consumer protection and pollution control where injunctive relief against the violator emerges as the most effective, if not the only, relief available. ${ }^{81}$ Prior to Mills the private suit for injunctive relief was less than a practical option; plaintiffs needed large damage awards from which the contingent fee device could generate legal fee payments. One commentator noted that the environmental lawyer faces the same kind of mammoth defendant as the stockholder's attorney, yet he lacks the fee-shifting advantages traditional in the stockholder's suit. ${ }^{82}$ Likewise, the failure of attorneys to realize the potential of the injunctive remedy in consumer actions has been linked directly to the fee implications of by-passing a damage award..$^{83}$

Although the plaintiff and defendant in the private injunctive action may lack the kind of formal relationship between the plaintiff and nominal defendant in Mills, the same policy considerations underlie both cases-the importance of the therapeutic benefit derived from statutory enforcement. Moreover, the effective support of private attorneys general would seem to mandate a judicial focus on the reception

78 Sive, supra note 77 , at 619 .

79396 U.S. at 394.

$80 \mathrm{Id}$.

81 Its flexible enforcement powers acting directly on the person of the defendant make it appropriate in preventing continuing violations. Starrs, The Consumer Class ActionPart I: Considerations of Equity, 49 B.U.L. REv. 211, 213 (1969). In addition, in pollution cases injunctive relief avoids the complex problem of allocating damages among a multitude of polluters. Note, Private Remedies for Water Pollution, 70 Colum. L. Rrv. 735, 747 (1970).

82 Sive, supra note 77 , at 618 .

83 Starrs, supra note 81 , at 212. 
of the recognized and costly "benefit" rather than on the formal relationship between the parties.

Such an approach would make a whole range of injunctive, lawenforcing suits practical, irrespective of the absence of a damage award. That focus would in addition support the creation of a fee incentive which can be of significant value even where a damage award is authorized. For example, sections $1983,^{84} 1985,^{85}$ and $1986^{86}$ of the Civil Rights Act authorize civil actions for damages. The courts have utilized these statutes to protect such varied freedoms as freedom of assembly, ${ }^{87}$ freedom from unreasonable search, ${ }^{88}$ and protection from batteries committed incident to an arrest or imprisonment. ${ }^{89}$ Yet here too the insufficiency of the potential award has resulted in circumscribed use of the authorized suits..$^{90}$

Moreover, the potential for a Mills impact goes beyond those statutes explicitly authorizing a private right of action. Where a statutory scheme does not admit of a private right, the courts are increasingly willing to imply such an action. For example, although the Voting Rights Act of 1965 is silent as to actions other than those initiated by the Attorney General, ${ }^{91}$ the Supreme Court did not hesitate to find an implied private right of action in the landmark case of Allen $v$. Board of Elections. ${ }^{92}$ Indeed, Mills itself involved such an implied right of action.

Moreover, the benefit rationale carried to its logical extreme cannot be limited to actions tied to concrete expressions of legislative intent. If law enforcement is the acknowledged benefit, there is little reason to view the law of contracts as being of any less importance than the Securities Exchange Act of 1934. Yet such a broad application of Mills would represent a complete reversal of the traditional fee system.

Of course the courts may ignore the logic of the "benefit" language; there are numerous ways in which the courts may limit Mills. First, the case may be confined to its facts in the same manner that the Supreme Court in Mills distinguished Fleischmann-discriminating be-

8442 U.S.C. \& 1983 (1964).

8542 U.S.C. \& 1985 (1964).

8642 U.S.C. $\S 1986$ (1964).

87 Hague v. CIO, 307 U.S. 496 (1939).

88 Lucero v. Donovan, 354 F.2d 16 (9th Cir. 1965).

89 Marland v. Heyse, 315 F.2d 312 (10th Cir. 1963).

90 Note, Civil Actions for Damages Under the Federal Civil Rights Statutes, 45 TExAs L. REv. 1015, 1035 (1967).

9142 U.S.C. $\$ \S 1973$ j(d)-(e) (Supp. I, 1965).

92393 U.S. 544 (1969), stating at 556: "The achievement of the Act's laudable goals could be severely hampered, however, if each citizen were required to depend solely on litigation instituted at the discretion of the Attorney General." 
tween statutes on the basis of the specificity of remedies contained therein. Arguments limiting Mills to a narrow factual situation gain weight from the particular statutory context in which Mills arose. The Securities Exchange Act explicitly permits private rights of action in three sections-18,93 $9(\mathrm{e}),{ }^{94}$ and $16(\mathrm{~b}) .{ }^{95}$ Of those three the first two specifically authorize fee shifting, but $16(\mathrm{~b})$ is silent on that question. However, in Smolowe $v$. Delendo ${ }^{96}$ the successful $16(\mathrm{~b})$ plaintiff was permitted to recover attorney's fees on the basis of the traditional fund exception. One analysis of Smolowe argues that it simply brought internal symmetry to the act by permitting fee shifting in all private actions including $16(\mathrm{~b})$. In this perspective, Mills signifies nothing more than the completion of the cycle by providing fee transfer for the newly implied private action under section 14(a). Such an analysis would limit a Mills application to those statutory schemes where a similar symmetry argument could be made. However, nothing in the language gives support to so restrictive an analysis, and one may suppose that if the Court was attempting to establish such a meticulous symmetry, it would have left something in the language to indicate that intent. Indeed, such a narrow interpretation would be entirely inconsistent with the broad tenor of the opinion.

Second, the "benefit" language is open to various technical interpretations. Mills ties the benefit to "corporate therapeutics,"97 and "the stress placed by Congress on the importance. of fair and informed corporate suffrage."98 The Supreme Court looked neither to the actual effect on the specific corporation nor to the motives of the plaintiffs. Placing judicial emphasis on either of these two criteria could produce radically different results under the same rule. Scrutinizing the intentions of the plaintiffs would undoubtedly uncover some private motive for the suit in almost every case, and examining the concrete effects on the particular corporation might rule out "minor" benefits such as temporary injunctions. Such a result clearly would contravene the core of the Mills process, whereby fees were shifted without regard to the eventual remedy. However, emphasis on these factors is a real possibility, not to be lightly dismissed.

The recent case of Yablonski $v$. United Mine Workers of America ${ }^{99}$

9315 U.S.C. \& 78r(a) (1964).

9415 U.S.C. § 78i(e) (1964).

8515 U.S.C. \& 78p(b) (1964).

98136 F.2d 231 (2d Cir. 1943), cert. denied, 320 U.S. 751 (1943). Here the successful 16(b) plaintiff recovered over $\$ 18,000$ for the corporation.

87396 U.S. at 396.

$98 I d$.

984 CCH LAB. L. REP. I 10,996, at 19,202 (D.D.C. 1970), appeal docketed, Nos, 24,560, 24,561, 24,562, 24,563 (D.C. Cir. Aug. 20, 1970). 
is an unfortunate example of the potential impact of such limitations. The case was brought under provisions of the Labor Management Reporting and Disclosure Act of $19599^{100}$ which are silent as to attorney's fees. Two other sections of the same act explicitly provide for fee shifting. ${ }^{101}$ Ignoring the broad policy arguments behind the Mills decision, the district court decided this case on a specificity-of-remedies test. Noting the "degree of similarity in the specificity of remedies between the LMRDA and the Lanham Act," "102 the court found the case to be governed by Fleischmann. As to the benefit criterion the court held that it was not satisfied that the suits "were intended to or did benefit the union except in the most indirect and theoretical way." 103

Aside from these potential, technical limitations, substantive questions of interpreting the actual nature of the fee transfer effected in Mills may arise. Mills held that the benefited class must pay the fees of the plaintiff whose suit had created the benefit. Yet this rationale was enunciated in the context of a stockholders' suit which, in a formal sense, was the action of a few stockholders on behalf of all the others. It might be argued that there was no real shifting of the burden of fees from plaintiff to defendant. The corporate defendant is made to pay merely as a means of distributing costs among the "true plaintiffs"that is, the stockholders on whose behalf the suit was brought. As stated in Mills:

To award attorneys' fees in such a suit to a plaintiff who has succeeded in establishing a cause of action is not to saddle the unsuccessful party with the expenses but to impose them on the class that has benefited from them and that would have had to pay them had it brought the suit. ${ }^{104}$

However, unless one is willing to torture the concept of identity of interest, the assertion that Mills does not involve true fee shifting fails to make sense in light of the fact situation. Here over fifty per cent of the stockholders were opposed to enforcement of the Securities Exchange Act regulations. Where a majority of the stockholders has an interest opposed to the litigation, the payment of fees by the corporation represents true fee transfer.

The possibility of imposing a general policy limitation on Mills seems difficult. The entire benefit concept implies a judgment that the advantages that fee shifting produces by encouraging private actions

10029 U.S.C. $\$ \$ 481(\mathrm{c}), 529,481$ (g) (1964).

101 Id. \$\$ 501(b), 431(c) (1964).

1024 CCH LAB. L. REP. 10,996, at 19,205 (D.D.C. 1970).

$108 \mathrm{Id}$.

104396 U.S. at $396-97$. 
outweigh the disadvantages of possible nuisance suits. Yet, in certain areas, the potential benefit to the public interest may be overshadowed by the possible negative impact of actions brought to remedy merely technical violations. This is especially true insofar as Mills alters the previous practice of proportioning attorney's fees in direct relationship to the financial award. ${ }^{105}$ No test which would successfully resolve such a conflict can exist consistently with the Mills rationale, where concrete tests based on economic benefit were discarded in favor of a focus on "the stress placed by Congress on the importance of fair and informed corporate suffrage."106 Since there is no reason to assume that Congress felt more strongly about the securities laws than about the civil rights laws, the consumer protection laws, or indeed any other legislation, the content of the Mills benefit test may be that the very existence of legislation evidences the beneficial effect of its own enforcement. However, to certify every enforcement of legislation as beneficial may be to invite an increase in suits whose chief motivation is their nuisance value.

Parallels drawn from equitable fee shifting under section $16(\mathrm{~b})$ of the Securities Exchange Act ${ }^{107}$ indicate that fees may be shifted even where no actual litigation has taken place. Although fee transfer in 16(b) takes place under the traditional fund rationale, the courts still

105 See Hornstein, supra note 65, at 663-64, arguing that a salvage analogy is and should be the principle followed in awarding attorney's fees in stockholder's suits.

106396 U.S. at 396 . While the maintenance of a direct relationship between financial benefit and fee award obviates the problem of nuisance suits, it implies significant limitations on its efficacy as a general principle of fee transfer. Where the amounts involved are small, the fee award will come nowhere near the actual costs of retaining counsel. To the extent that Mills may herald the dissociation of the fee award from the dollar amount of the damages, it may breathe new life into consumer actions, for instance, where characteristically the amounts involved are not large.

10715 U.S.C. \& 78p(b) (1964):

For the purpose of preventing the unfair use of information which may have been obtained by such beneficial owner, director, or officer by reason of his relationship to the issuer, any profit realized by him from any purchase and sale, or any sale and purchase, of any equity security of such issuer (other than an exempted security) within any period of less than six months, unless such security was acquired in good faith in connection with a debt previously contracted, shall inure to and be recoverable by the issuer, irrespective of any intention on the part of such beneficial owner, director, or officer in entering into such transaction of holding the security purchased or of not repurchasing the security sold for a period exceeding six months. Suit to recover such profit may be instituted at law or in equity in any court of competent jurisdiction by the issuer, or by the owner of any security of the issuer in the name and in behalf of the issuer if the issuer shall fail or refuse to bring such suit within sixty days after request or shall fail diligently to prosecute the same thereafter; but no such suit shall be brought more than two years after the date such profit was realized. This subsection shall not be construed to cover any transaction where such beneficial owner was not such both at the time of the purchase and sale, or the sale and purchase, of the security involved, or any transaction or transactions which the Commission by rules and regulations may exempt as not comprehended within the purpose of this subsection. 
have had difficulty defining its boundaries. For example, awards of attorney's fees have been made where the stockholder's efforts have caused the insider to pay up without the institution of an action.

If the objective is the recovery by the corporation of unlawful profits, would it be reasonable to say that a stockholder shall be entitled to all his expenses if he needs to bring suit, but he shall be denied reimbursement where the same benefit to the corporation has resulted without the necessity of legal proceedings but at less expense? That would be penalizing efficiency and expediency. ${ }^{108}$

More recent opinions have qualified the right to award fees independent of an actual court action. In Blau $v$. Rayette-Faberge, Inc., ${ }^{109}$ the Second Circuit attempted to find a "middle ground" between complete denial of fees and automatic shifting which would encourage attorneys to attempt to find a cause of action before the corporation does.

Reimbursement for information leading to corporate recovery will be allowed only if the corporation has done nothing for a substantial period of time after the suspect transactions and its inaction is likely to continue. ${ }^{110}$

Clearly fee shifting under 14(a) may give rise to the same kind of prelitigation fee demands inspired by the 16 (b) development, resulting in the same tenuous and difficult efforts to find a viable middle ground.

In the corporate context, the prospect of fee shifting after long litigation about technical violations, or an abundance of pre-litigation fee transfer demands, may tip the burden too far against the corporation and result in an increasingly timid corporate directorship. A negative experience in the corporate sector can be expected to cancel any potential for an expansion of the Mills principle. On balance, it is possible that the courts may discover that the nuisance value of Mills may outweigh the enforcement benefits. The nuisance potential may become particularly acute if Mills is not expanded to include the successful defendant as well as the successful plaintiff, but authority for such an expansion is hard to find in the Mills opinion. The imperatives of encouraging private law enforcement do not mandate shifting the fee burden from the successful defendant. Indeed, such a result might act

108 Dottenheim v. Emerson Elec. Mfg. Co., 77 F. Supp. 306 (E.D.N.Y. 1947). See also Globus, Inc. v. Jaroff, 279 F. Supp. 807 (S.D.N.Y. 1968); Henss v. Schneider, 132 F. Supp. 60 (S.D.N.Y. 1955); and L. LOSs, SECurITIES REgulation 1054 (2d ed. 1962) noting, "This view, it is understood, has been consistently followed in a number of unreported instances. It. is certainly sound, given the present statutory scheme."

109389 F.2d 469 (2d Cir. 1968).

$110 \mathrm{Id}$. at 473 . 
to chill the private enforcement potentials that Mills attempts to realize. Yet to reserve the advantages of fee shifting to plaintiffs alone may not only offend a court's refined sense of mutuality, but may result in an overburdening of a legal system already threatened with congestive breakdown.

\section{Concrusron}

Mills did not intend to restructure the entire fee system. It was an attempt to reconcile an outmoded fee process with what the Court recognized as the compelling policy considerations of a new era. Explicit authorization to shift fees from successful defendants or even from all successful plaintiffs was not even considered. Yet the logic of the case provides no limitations, the principles evoked are without bounds, and the language chosen lends itself easily to the most expansive development. Logically, one of two things must happen: either judicial discretion to grant fees on policy grounds will result in universal fee shifting from the successful party, or the courts will withdraw to the traditional position, denying any fee transfer without specific statutory authorization. Mills represents an uneasy half-way house between these two extremes. 